Anthony Walker

is a founding and senior partner of architects Damon Lock Grabowski and Partners, visiting professor for Kingston University, visiting lecturer for the Architectural Association, founding member and chairman of the Leisure Property Forum and an Architect Accredited in Building Conservation.

Keywords:

retail, leisure, community, sustainable, historic, conservation
Professor Anthony Walker Damond Lock Grabowski 11-29 Fashion Street London E1 6PZ, UK Tel: +44 (o) 2074263630 Fax: +44 (o) 2074263631 E-mail: a.walker@dlg-architects.co.uk

\section{Case study: The interaction between commercial objectives and conservation in a city- centre mixed-use development}

\author{
Anthony Walker
}

Received (in revised form): 9 May 2003

\begin{abstract}
A number of discernible trends have been emerging in the retail and leisure field arising from several different sources. Central government policy has sought through sequential testing to drive activities back into town centres, conservation interests have increased awareness of the significant effects of historic buildings on the quality of the urban environment and an increasing interest in sustainability beyond the narrow confines of energy conservation has led to a better evaluation of what really determines sustainable development in both towns and individual buildings.

In addition to these public interest pressures, the commercial and investment world has seen retail and leisure development as one of the key sustainable investment opportunities. The experience economy requires an environment equally responsive to the demands and needs of its users.

The Light is a mixed-use development in the centre of the city of Leeds. Combining several different aspects and including both historic listed buildings and new construction, it has received seven awards from specialist bodies in the first ten months since its opening, including the British Council of Shopping Centres (BCSC), the Leisure Property Forum and the local People's Award for 2002.

This paper examines the influence of the various policies and commercial objectives involved, combined with the serendipity of site assembly, in creating a development which responds wholeheartedly to current government policy and provides a benchmark for future projects.
\end{abstract}

\section{INTRODUCTION}

'The Light is not a shopping centre in the traditional sense, but it is a superb example of mixed-use urban regeneration and, as such, we felt it deserved an award. Totally in line with Government thinking, it successfully integrates retail, leisure, restaurant and hotel uses within new and existing buildings over five levels centred on a major covered public space that forms a living extension to the heart of Leeds. ${ }^{1}$ 
Case study: The interaction between commercial objectives and conservation in a city-centre mixed-use development

\section{Era of comprehensive development}

This is the way in which Nigel Woolner, Chairman of the BCSC Awards committee, introduced the special award given to the Light, and his statement sums up the objectives and the lessons to be learned from this development.

The merchant and the publican have been at the heart of the town for hundreds of years. Occupants of the medieval city enjoyed many spectacular and elaborate entertainments, but they tended to be sporadic and so did not give rise to permanent structures. ${ }^{2} \mathrm{~A}$ turning point came with the development of 'polite society', which became established during the 17th century. Polite society as a means of enabling contact between those not in the upper echelons of the community became an important element in the development of towns and cities because it was a permanent institution and with it came the need for places in which it could operate. The leaders were the arbiters of taste and of who and what was accepted and, according to Girouard, required 'Theatres, opera houses, pleasure gardens, assembly rooms, race-courses, coffee-houses, shops, entire neighbourhoods and ultimately entire towns' to cater for their pleasures. $^{3}$

Concerns from the middle of the 19th century resulted in recognition of the need for clean water, air and light and the necessity of planning to achieve these objectives, and the early part of the 20th century saw the establishment of regulatory planning systems. ${ }^{4}$ By the middle of the century it was realised that these systems were inadequate for the burgeoning urban development, and the resulting 1947 Act required local authorities to publish development plans based on a physical, social and economic survey moving the focus from amenity to one of control over land use, a principle feature of which was the introduction of zones for specific uses.

The 1960s saw an emphasis on new building, increased state control and large-scale projects with high-rise housing and comprehensive central area developments. ${ }^{5}$ Single-use developments suited developers well: few complications of tenure, simple forms of construction, reduced risk and increased profit. Actions by various groups and individuals with publications such as The Rape of Britain in $1975,^{6}$ Townscape in $1961^{7}$ and How to Play the Environment Game in $1973^{8}$ increased awareness of the loss of important historic fabric and stimulated a growing interest, initially in its protection, and now in its viable and effective use.

In the 1960s, 1970s and 1980s leisure buildings were still primarily stand-alone structures - cinemas, bowling alleys and public houses - but shopping developments had grown into larger and larger complexes, self-contained with integrated car parking and an increasingly similar range of national retailers. Concerns arose about the loss of identity, and designers sought an increasingly individual image for the shopping centre to counteract the ubiquitous nature of the traders, but this increasingly detracted from the retailers' own presentation to the extent that a form of 


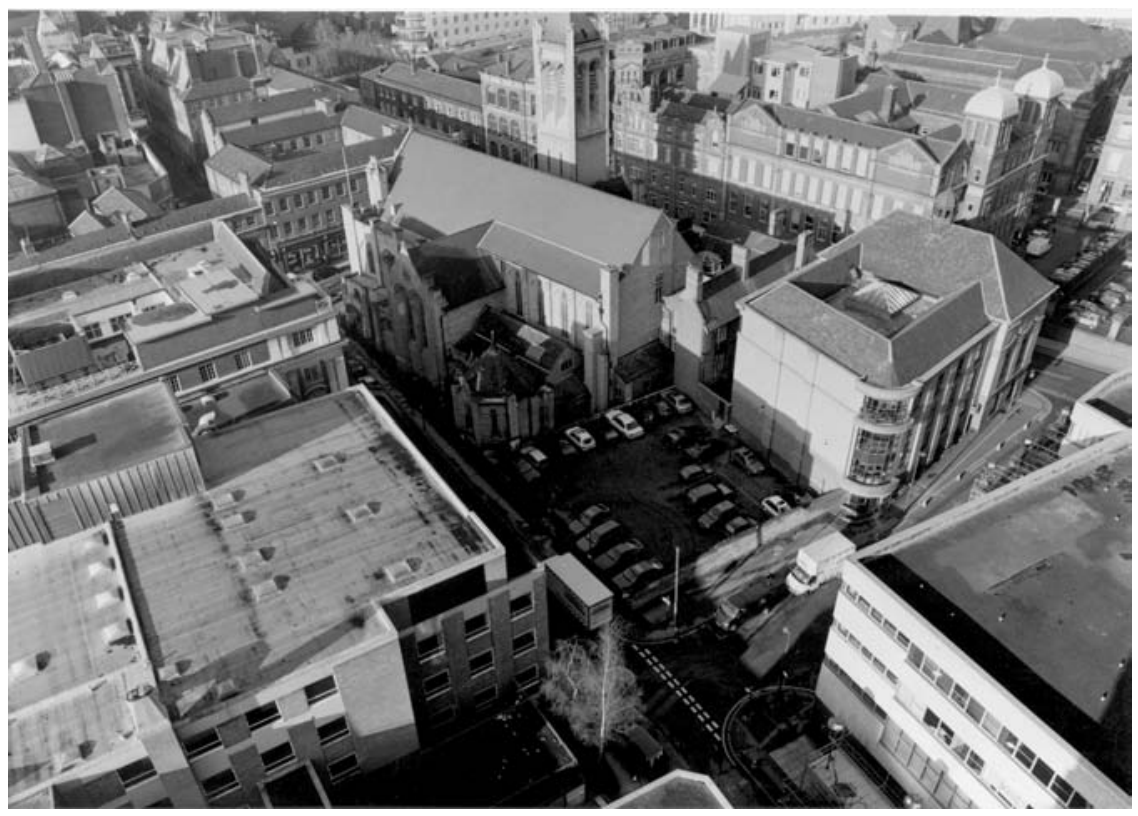

Figure 1: Aerial view of site

subtractive refurbishment, removing rather than adding to the features in a shopping centre, became popular. ${ }^{9}$

At the same time commercial organisations were recognising that there was a need to provide added value to their products. 'Lifestyle' retailing, where the product helped to identify the purchaser's status, drove a whole sector of the industry. Retailing and leisure organisations, and indeed the whole service industry, recognised the need to give more than the basic functional requirements ${ }^{10}$ and Pine and Gilmore coined the term 'the experience economy"11 in a study subtitled Work is Theatre and Every Business a Stage. They set out to demonstrate the value that can be added to any product or service by recognising that it is the experience of that purchase or service which is fundamental to its success and that many transactions involve the customer settling for something less than they really want — what Pine and Gilmore call customer sacrifice, a term which might well strike a chord with customers leaving some shopping centres. The experience economy philosophy sets out to tailor the experience to meet the customer's desires, thus rendering the experience unique and integral to the community which it serves.

In a poll conducted by MORI for English Heritage in 2002, ${ }^{12} 86$ per cent of the residents considered that heritage is worth saving and 94 per cent that it plays an important part in regenerating rundown areas. Interestingly, 79 per cent believed that consideration should be given to the protection of modern buildings for future generations. It is apparent that the scope of involvement in the existing built environment is supported by the public and is likely to expand, with an increasingly proactive approach in the future. 
Case study: The interaction between commercial objectives and conservation in a city-centre mixed-use development

Several forces are coming together with a common objective: a commercial need to create an experience relevant to its particular location, a community interest in the preservation of heritage and vitality and a global interest in economic, social and environmental sustainability. This is a fundamental shift in community involvement and interaction which is likely to involve more active public debate and which also has the potential for greater rewards for all participants. The use of historic buildings for commercial uses is not new, as Tiesdell, et al.'s study of historic quarters demonstrates, ${ }^{13}$ but the active participation of the commercial sector and the blending of retail and leisure activities with their sometimes conflicting requirements still has a long way to go.

Here a recent development, the Light in Leeds, completed in 2002, provides a rewarding case study, not least because it has received a specific award demonstrating public approval in the 2002 Leeds People's Award as well as recognition and praise from the retail and leisure industries: it is a development which by its very complexity has found renewed value in obsolete but listed buildings which are of historic interest in the development of Leeds, while creating an integrated experience which is of positive benefit for a variety of community activities.

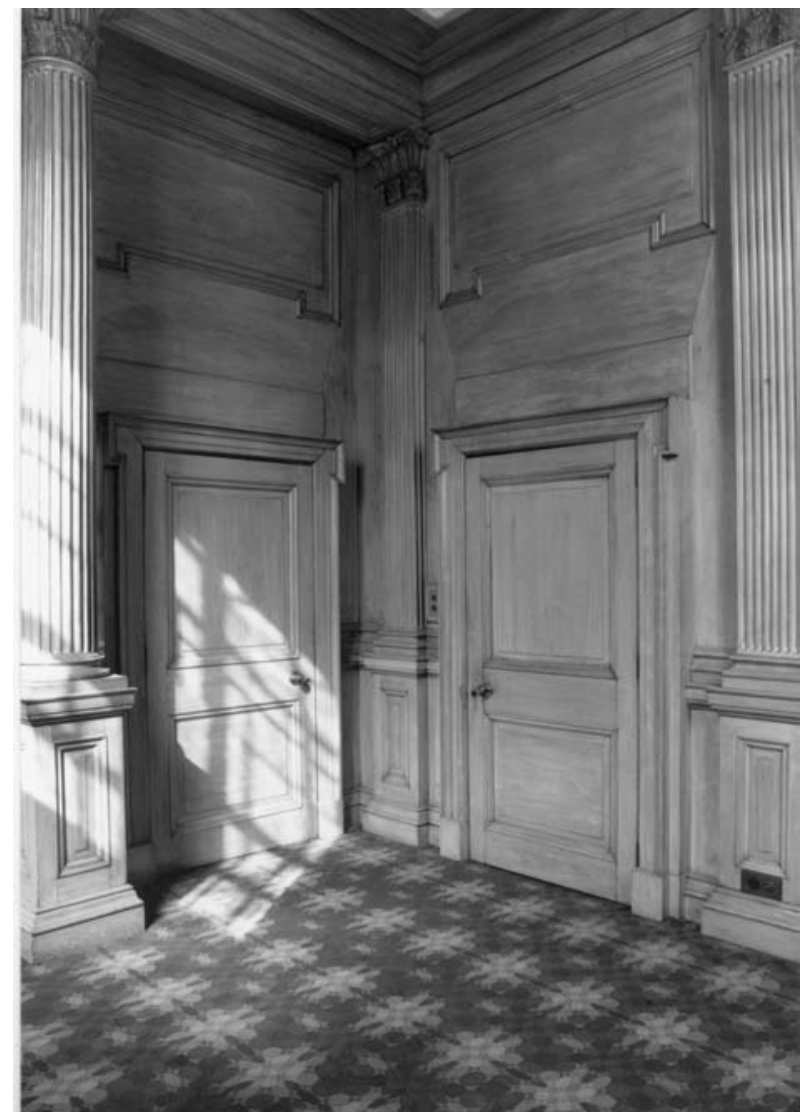

Figure 2: Bank manager's office illustrating the qualities of the interiors to be retained and reflecting English Heritage's interest in a wider range of architectural conservation 
1920 development of The Headrow

\section{LOCATION}

The site is at the commercial heart of Leeds, adjoining St Anne's

Cathedral and bounded by The Headrow, Albion Street and Cookridge Street, and it includes two existing streets, namely Upper and Lower Fountaine Streets (see Figure 1).

At the time of the Domesday Book Leeds was little more than an agricultural village but by 1726 John Cossins in his New and Exact Plan of the Town of Leeds shows a town of fine houses with the medieval pattern of Briggate, Kirkgate, Boar Lane, Vicar Lane and Headrow at its core. Leeds then grew rapidly, mainly because of the prosperity of the woollen cloth industry but reflecting also a more general industrial growth stemming from the nearby coalfields and its access by waterways to the Baltic ports. By 1901 the population was 428,953 , making it the fifth largest city in England and it was recognised not only as a great engineering centre but also as the hub of the cloth industry. ${ }^{14}$

St Anne's Cathedral, which adjoins the north-west corner of the site, was built in 1904 to replace an earlier building demolished for road widening. The 20th century saw major road-building works and in 1924 it was proposed to create a great new street from Victoria Square leading towards Quarry Hill, which would incorporate Upper Headrow and Lower Headrow and replace the existing shopping areas. This would sweep away buildings from the industrial revolution and replace them with examples of the 20th century. The name 'The Headrow' was decided by a competition organised by the Yorkshire Post, whose Guide in 1935 claimed that 'The centre of Leeds has been transformed ... most of the shopfronts have been modernised ... and naturally the big new

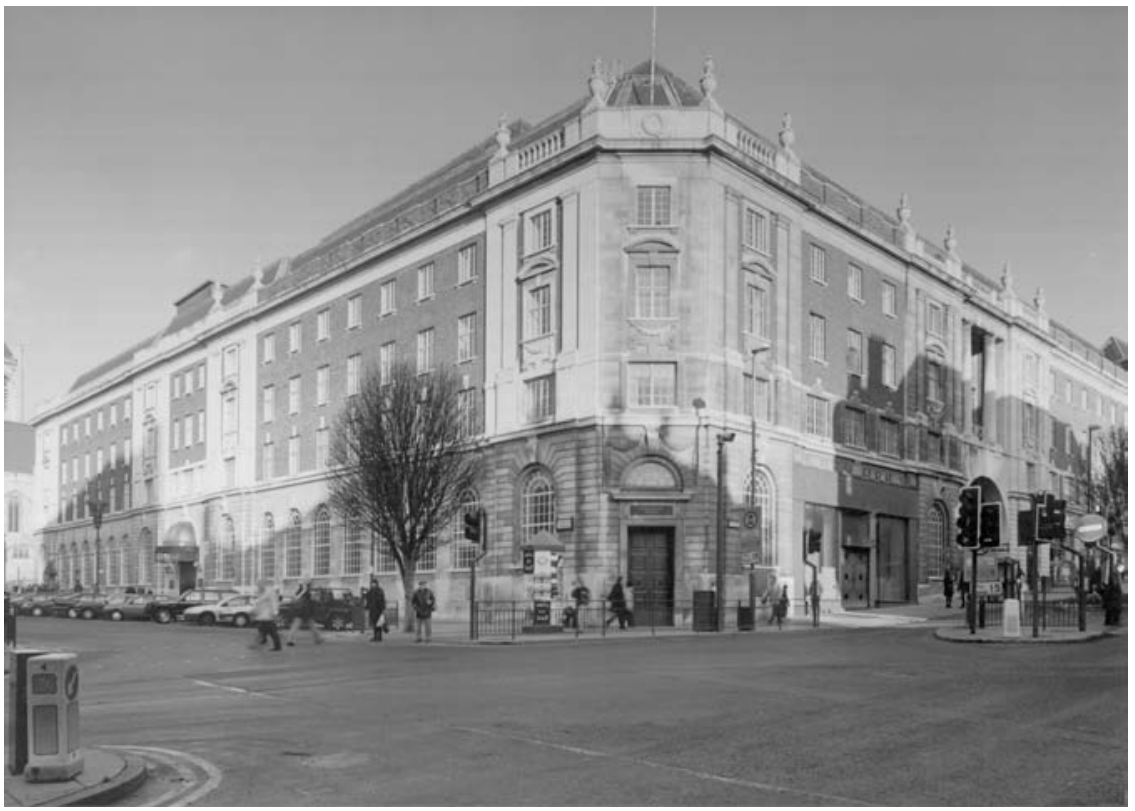

Figure 3: Headrow retains elevation of scheme 


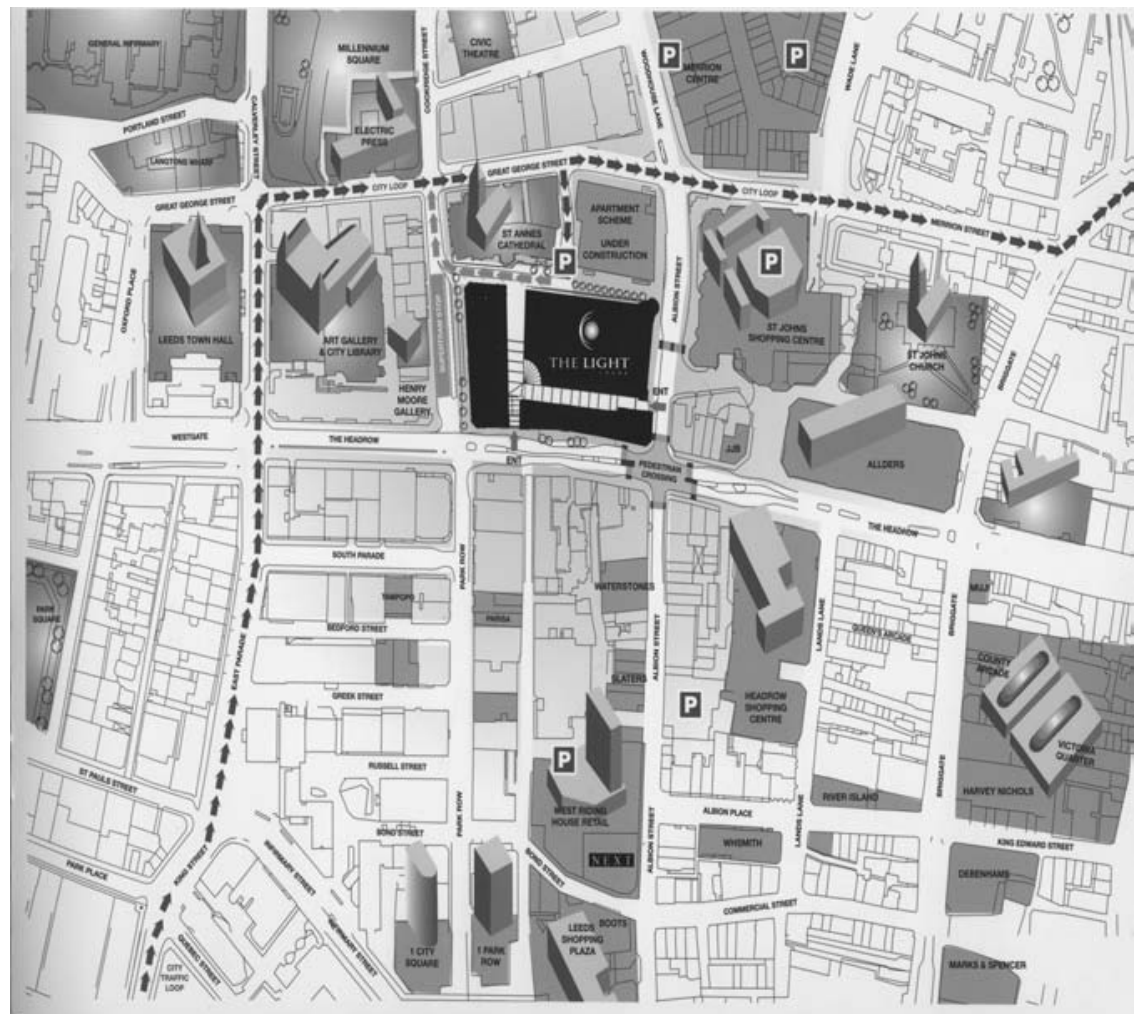

Figure 4: Location plan

street The Headrow ... electric signs have become popular so that by day and night the city is a great attraction ...,15 These works, which were no doubt seen at the time as a radical intervention in the city, also gave rise to opportunities to create some fine contemporary buildings. Sir Reginald Bloomfield was appointed in December 1925 to prepare designs for the elevation of the buildings in the new street, which are claimed to be based on designs undertaken for Regent Street in London. The buildings were a combination of brick and stonework, and rise towards a high point about a third of the way along The Headrow, stepped with each junction somewhat crudely articulated by a doorway.

One of these new buildings, a new headquarters for the Leeds Permanent Building Society which had been founded in 1848, was erected at the junction of The Headrow and Cookridge Street close to the town hall and cathedral. This building, known as Permanent House, was planned by G. W. Atkinson to designs by Sir Reginald Bloomfield. It was described in Francis Frith's historic photographic record ${ }^{16}$ as being clearly designed to impress with its classical swags, urns and pillars facing on to The Headrow, which, at 80 feet wide, was a major thoroughfare and ten feet wider than Union Street in Aberdeen. The elements of the main façade were repeated in varying forms on a number of buildings on the north side of The Headrow, in particular the original Lewis's department stores which opened in 1932. 


\section{Development potential at end of twentieth century}

\section{Leeds shopping}

These buildings, together with a contiguous building owned by Leeds City Council facing The Headrow, formed an L shape behind which lay Upper and Lower Fountaine Streets. In the arms of the L further post-war development took place with an indifferent tower block known as Albion House which was also occupied by the Leeds Permanent Building Society during the 1970s, and some other smaller buildings of varying quality and age facing on to Albion Street. There were a number of different ownerships apart from the two major interests. To the north-east stood another tower block, Dudley House, which was initially owned and operated by the Yorkshire Bank and later by the Norwich Union.

Permanent House was built in two phases, the original part in the early 1930s and the later stage in the 1950s in the same style but with a different form of construction. It is linked to The Headrow buildings by a stone archway, which was to become an important element in the development of the design concept and discussions with English Heritage and the conservation officers. As the building society expanded it closed off a section of Lower Fountaine Street, cutting off the view of the chapter house on the corner of the cathedral.

By the mid-1990s the Leeds Permanent was incorporated into the Halifax Building Society and, along with other sites in the locality, the buildings became redundant. The Halifax at the time was purely a building society and not able to act as a developer, and it began to market the site independently of the city council, which had indicated that it was prepared to consider disposal of The Headrow buildings which were principally occupied by the Planning and Development Department with some small shops at ground level facing The Headrow. A number of developers looked at the site: the prime use was for offices but the restrictions of the listed buildings, which were largely cellular in form, meant that a high proportion of the site did not meet modern office standards.

Attempts by some developers and their teams to overcome this with demolition behind a retained façade were not favourably received at the time (see Figure 3).

The strength of Leeds's shopping lies not in a single major centre but in a diverse and disparate series of centres of varying quality scattered over the central area from Boar Lane and the railway station in the south to Woodhouse Lane to the north and between Briggate to the east and Park Row to the west (see Figure 4). Within this area lie the Merrion Centre, St Johns Shopping Centre, Headrow Shopping Centre, County Arcade, the Victoria Quarter, Leeds Shopping Plaza, Trinity Street Arcade, a speciality centre in the Corn Exchange and a series of individual stores such as Next in West Riding House, Allders on The Headrow and Debenhams and M\&S in Briggate. Albion Street, which runs past the Light, crosses the area north to south. One of the problems in central Leeds was, and still continues to be, a shortage of larger shop units, and while 
Case study: The interaction between commercial objectives and conservation in a city-centre mixed-use development

\section{Site constraints}

\section{Basic concept}

the Light was not seen as being prime pitch it did present an opportunity to address that need.

In a joint venture J. F. Finnegan and the Argent Group agreed a conditional purchase of the site for a new concept of 'mixed-use, mainly leisure-based' development which required that a planning application be made within three months. A key to this new approach lay in the use of the Permanent building as a four-star hotel which would take advantage of its cellular nature and of the period interiors.

DLG Architects were approached by the joint developers in February 1997 to undertake this project, with the requirement that a planning consent had to be obtained within a year.

\section{INITIAL CONCEPTS}

Apart from the listed buildings on the site, including St Anne's Cathedral, there were a number of other interesting issues to be addressed. A steep change in level meant that opposite corners of the site were one level apart. It was anticipated that some large floorplates would be needed for the retailers' activities, and the need for greater permeability linking the adjoining retail areas and taking advantage of the pedestrian flows was recognised. The planning authority had a principle of requiring 20 per cent new public space for this scale of development and were also seeking a contribution to the proposed new tram line which would run directly across the front of the site.

From a practical point of view access to all the buildings was not available and so it was necessary to estimate physical dimensions to arrive at the best form of construction. It was of course particularly important to determine the most appropriate ways in which to adapt the historic buildings.

A major part of the project was to provide new leisure facilities and restaurants. The large volumes which multiplex cinemas and health and fitness organisations require could not be accommodated within the existing structures and would require the creation of substantial new space.

The basic concept was established at an early stage: to retain the two main listed buildings, and to unblock Lower Fountaine Street, creating a lower arcade linking The Headrow and St Anne's Cathedral and an upper one from the same point at 90 degrees through to Albion Street. These changes reflected the original street pattern, opened up the back elevations of the historic buildings to public view (those on The Headrow had some very interesting storey-height steel windows) and allowed a new block of development within the arms of the $\mathrm{L}$ created by the two arcades with the potential to meet the specific needs of the large leisure users. The major retail units would face outwards on to The Headrow, which was the traditional retail frontage, and extend back under the upper-level arcade which allowed for the large floorplates. 

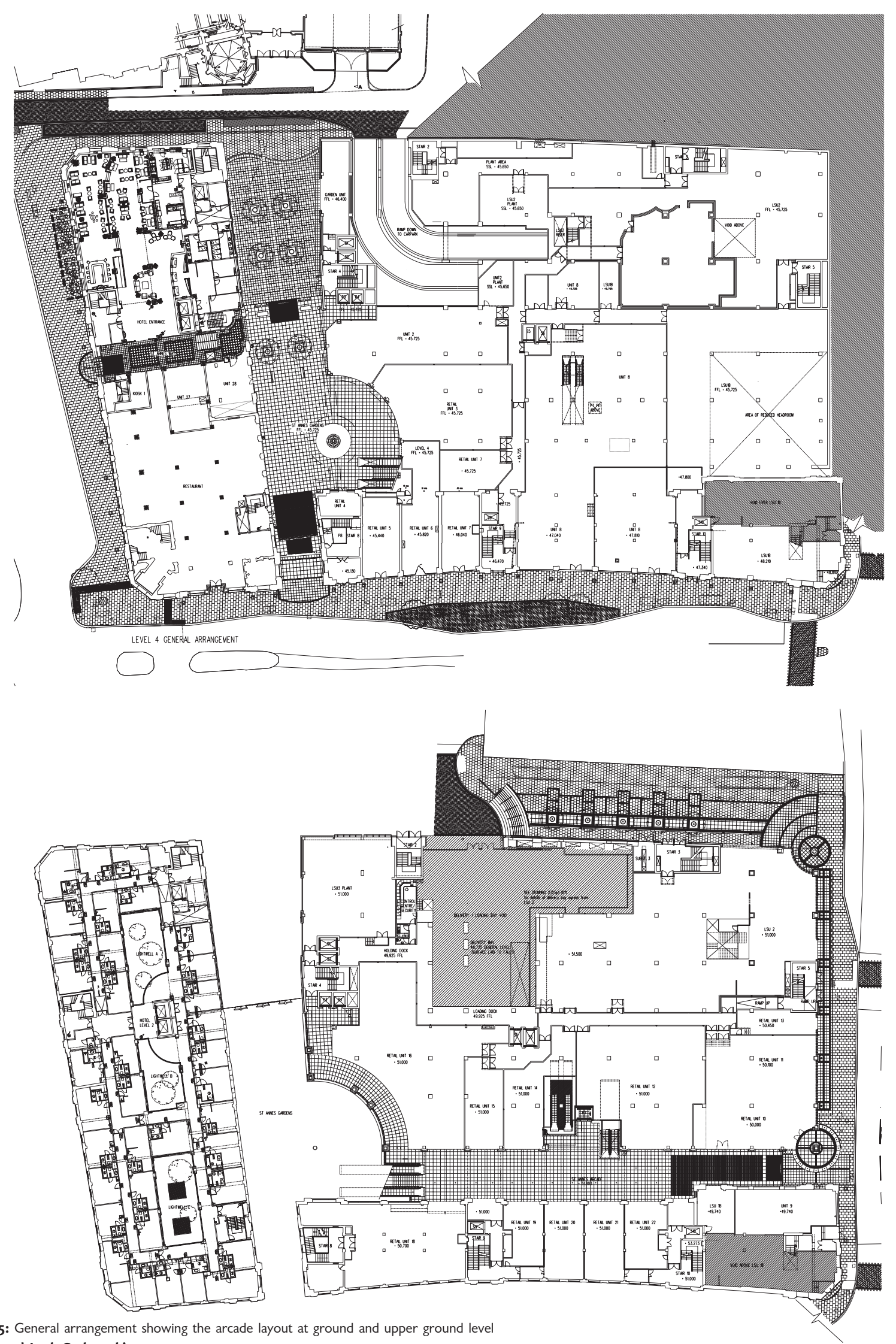

Figure 5: General arrangement showing the arcade layout at ground and upper ground level (C) Damond Lock Grabowski 
Case study: The interaction between commercial objectives and conservation in a city-centre mixed-use development

By siting the multiplex on two levels, starting at one level above the upper arcade, the development provided four natural levels of development with street frontages on the two main levels. There remained the problem of linking the new buildings with The Headrow buildings at the upper levels to achieve commercial value from them, and here the solution lay in the use of bridges, inspired by similar links between the front and back buildings at Shad Thames. A key to creating a layout both vital and viable was to ensure that the cinema operator provided an open foyer looking out over the main arcade.

The layout design resolved a number of the conflicts between the different forms of leisure activity, the different operational times for the retail and leisure uses and the need to provide the longest possible trading time for the restaurant and catering units. The planning requirement for the development to serve a full spectrum of leisure age groups posed potential problems with regard to conflict between family entertainment and the customer profile for nightclubs and bars, but the internal street and external frontage afforded the opportunity to segregate these activities. This demonstration of the interactive relationships between the internal and the external emphasised the integration of the development with the city and adjoining areas.

\section{PLANNING ISSUES}

Because of constraints arising from the land purchase, the planning application was made on 20 June 1997, just four months after the original instructions were issued. This timescale inevitably meant that many detailed aspects of the design were still evolving after the application had been submitted. At that time the designated uses on the site were offices for the upper parts with ground-level retail and the possibility of some A3 use. Although not part of the unitary development plan (UDP), the planning department indicated that a hotel might be an appropriate use for Permanent House.

There were a number of parties interested in the planning application: apart from the local authority as planners, the Civic Trust, English Heritage and the 20th Century Society were invited

\section{Conservation issues} to make comments on the proposals. There was support for the basic principles - the use of Permanent House as a hotel was welcomed, as was the opening up of the views of the cathedral but there were some reservations. These focused on the 'new-build' element of the project and the amount of development it contained. ${ }^{17}$ It was, however, an important element both for the financial viability of the project and to achieve the mix of activities and variety of elements needed to create an overall experience which would enhance both the value of the commercial space and the role of the buildings in the city of Leeds. It was made clear by the architects from the outset that the intention was not to create a standard shopping mall but a complex design with distinctively different uses and activities of a character to reflect the traditional 
Access and permeability

\section{Client change}

Leeds arcades. A development of this scale naturally has a significant servicing requirement, and there were concerns that the servicing arrangements might leave the cathedral on what in effect would be a traffic island.

The planning authority was also concerned about the degrees of access to and pedestrian flow within the site. One issue to be addressed was that the new supertram would run past and it was considered essential that the development did not form a block to pedestrian movement, as a result of which an additional arcade entrance was introduced. The second concern was that since this was to become a private space the opening hours might be limited and thus the public denied access to the buildings. How to deal with the enclosure of the central space was a bone of contention: should the glazing necessary at the historic archway be placed behind the stonework or integrated with it? Where should the demarcation be in the approach to the cathedral?

\section{THE DEVELOPMENT FINALISED}

The final development is for 350,000 square feet $\left(32,515 \mathrm{~m}^{2}\right)$ of retail and leisure uses comprising 24 retail units, six restaurants and bars, two nightclubs, a 2,900-seat 13-screen multiplex, 26,000 square feet $\left(24,154 \mathrm{~m}^{2}\right)$ for health and fitness, a four-star 150-bed hotel and 425 parking spaces.

The success of the project lies in the positive use of the levels on the site, which can be seen from the sections through the building. These allowed natural multilevel trading and inspired some dramatic spaces, which have enhanced the public realm. This area of public space has been fundamental to both the economic and the cultural value of the project, and creates an area which is both commercially viable and a delight at all times of the day and night.

\section{CHANGES}

Soon after the architects were appointed and during the very intense studies for the initial planning application, the possibility was mooted that the Norwich Union tower block, Dudley House, should be incorporated. As there appeared to be little benefit in this other than to provide a more cost-effective car park to service the development, and since it was known that the planning authority had different aspirations for this site, it was not incorporated. It is now being developed as a residential complex.

The major change, however, was on the part of the main client body. Initially this was to be a joint venture between a local contractor, J. F. Finnegan, and Argent Group, an innovative property developer, but during the planning application process things changed. Argent was taken over by Hermes, a major fund manager. Argent already owned the St John's centre opposite the site, while Hermes owned the Headrow Centre, so there was little appetite for owning another large scheme in the middle of Leeds and Finnegan's were left looking for a new joint-venture partner. 
Case study: The interaction between commercial objectives and conservation in a city-centre mixed-use development

At the same time the Halifax Building Society had changed to become a bank and had taken on Jon Lloyd to implement a development programme. Halifax approached Finnegan's to buy out their interest in the scheme and, following a successful outcome to negotiations, they took over the project, appointing St James Securities to act as development managers on their behalf. This was a positive move, as the new client had a vested interest in the success of the development. It was fortunate indeed that the new owner retained the commitment to the original concept and to a development requiring very positive management.

By the time planning consent was obtained in April 1999 the scheme had already undergone significant changes, in particular to clarify the very difficult set of relationships between the development and the cathedral. A new application for this area was made in May, which resolved the dilemmas, partly by changes to the cathedral requirements and amendments to the plans for the cathedral hall. The application also included some new details for this area arising from suggestions by the design team following a detailed appraisal of the existing proposals, and this was approved on 22 December 1999. In the meantime 'stopping up' orders were required in order to be able to build over or close the streets, and these were received from the Government Office for both Upper and Lower Fountaine Streets.

\section{INTEGRATION INTO THE CITY}

The development is seen by all concerned as wholly integrated into the city, not just through physical relationships but in the way in which it trades and the uses to which it is put. Close links have been formed with the community, and soon after completion a Palm Sunday service was held in the main courtyard. This degree of interaction is an essential part of the development and is reflected in its intrinsic inward- and outward-looking nature (see Figures 6-9).

\section{TENANTS, LETTINGS AND MANAGEMENT}

The majority of the building was vacant, but one tenant (Greggs Bakery) had to be accommodated throughout the project with no interruption in trading. Key tenants were established as pre-lets, including the hotel, cinema and health and fitness club. For this last use the initial tenant was Healthlands, which went into receivership before it was ready to fit out the premises and was replaced by Esporta, necessitating some changes to the layout and planning consent.

The development provides 350,000 square feet $\left(32,515 \mathrm{~m}^{2}\right)$ of retail and leisure space with 24 retail units and the following major tenants:

- Ster Century, with 13 screens and 2,928 seats, including disabled, on two levels approached from an open foyer on the second level

- Esporta: 26,000 square feet $\left(24,154 \mathrm{~m}^{2}\right)$ on two levels and including a $20 \times 10$-metre pool

- Radisson Hotel: 150 bedrooms, four star 


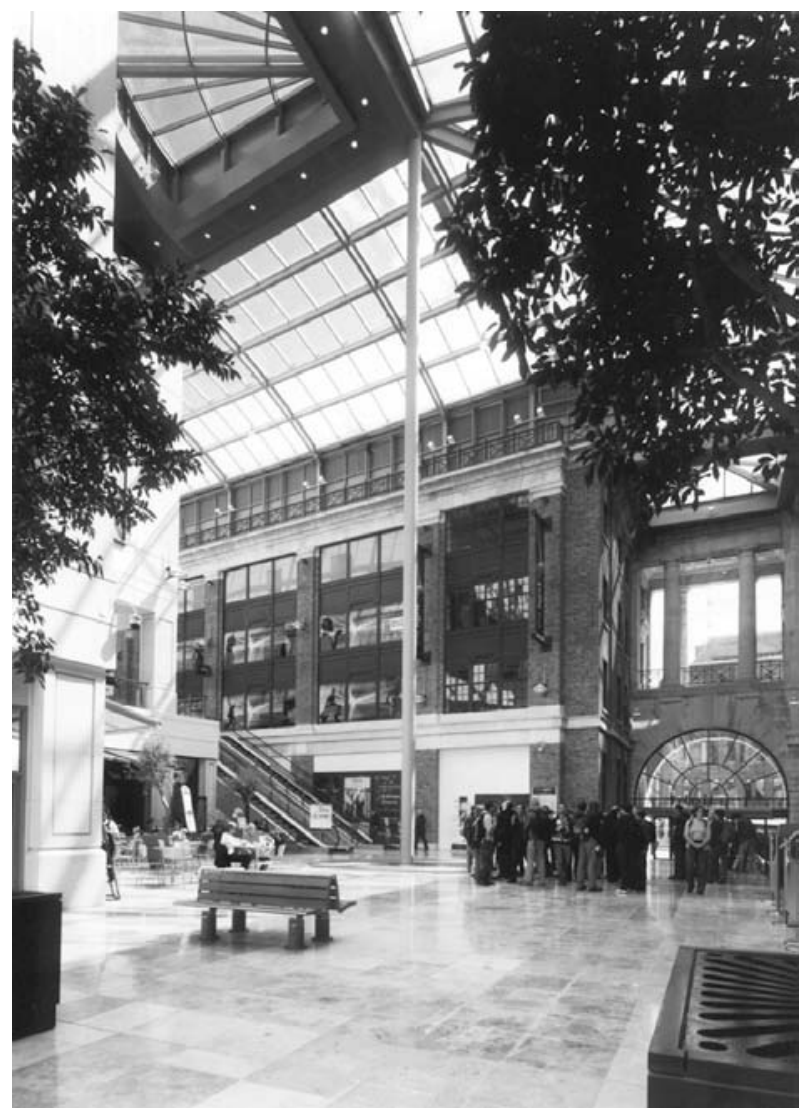

Figure 6: View from the cathedral

- Tiger Tiger: 19,600 square feet $\left(1,820 \mathrm{~m}^{2}\right)$

- Life Café: 15,000 square feet $\left(1,393.5 \mathrm{~m}^{2}\right)$

- Browns: 300 covers, 15,000 square feet $\left(1,393.5 \mathrm{~m}^{2}\right)$

- Nando's

- Ma Potters

- Greggs

- Probito

- Rockport

- Mikey.

There is a 425 -space car park with direct access into the main public space, and the development is adjacent to one of the proposed new main supertram stops. It also is directly served by the Leeds loop, which is the main traffic circulation route around the centre.

Within six months of opening the centre was 92 per cent let, and a recent Experian survey ${ }^{18}$ attributed Leeds's rise from fourth to third best shopping city in the UK to the key part played by The Light. What had at best been a secondary retail pitch has definitely changed to an emerging prime position and the impact has been to enhance the perception of the whole of The Headrow. 
Case study: The interaction between commercial objectives and conservation in a city-centre mixed-use development

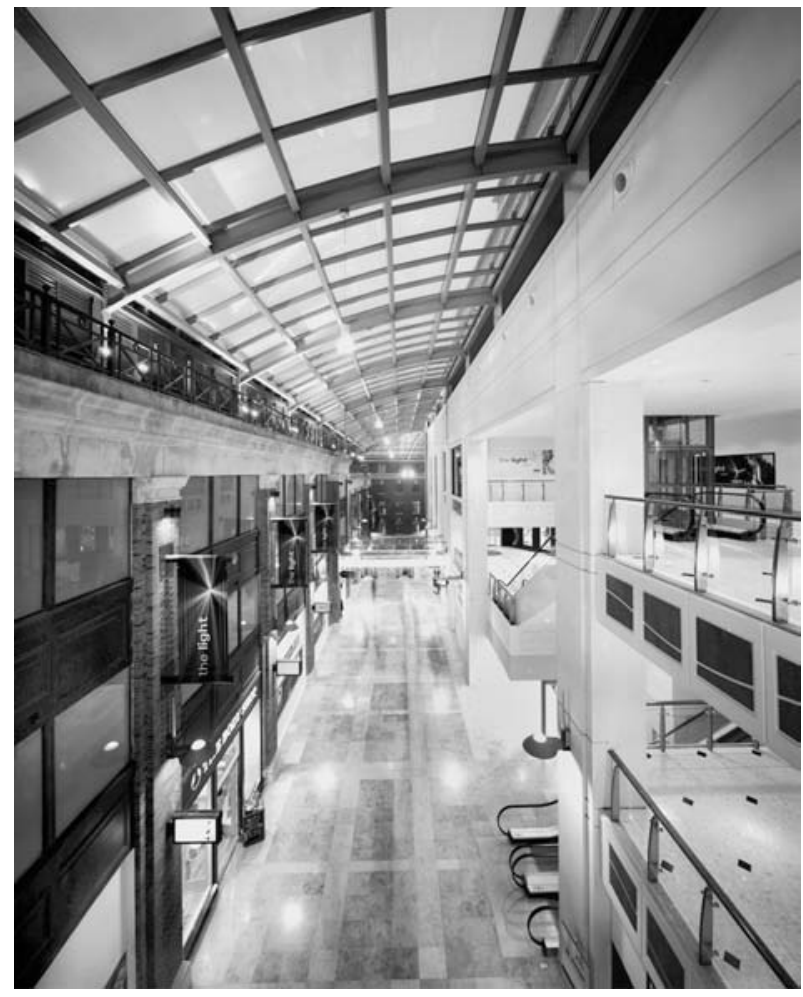

Figure 7: View from the Radisson hotel

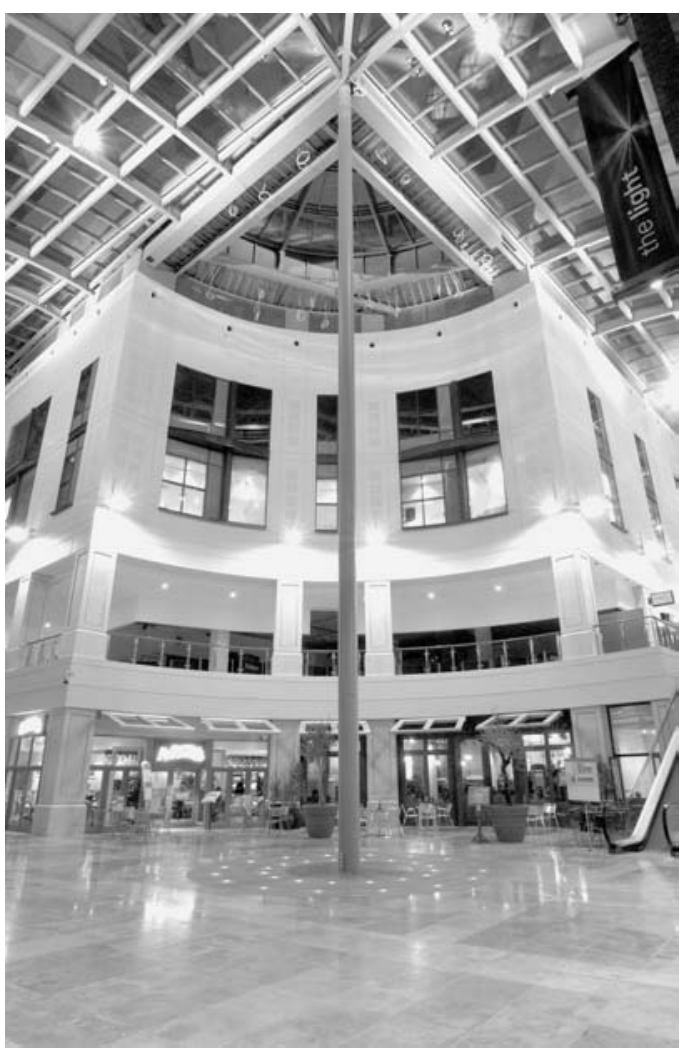

Figure 8: Courtyard interior 


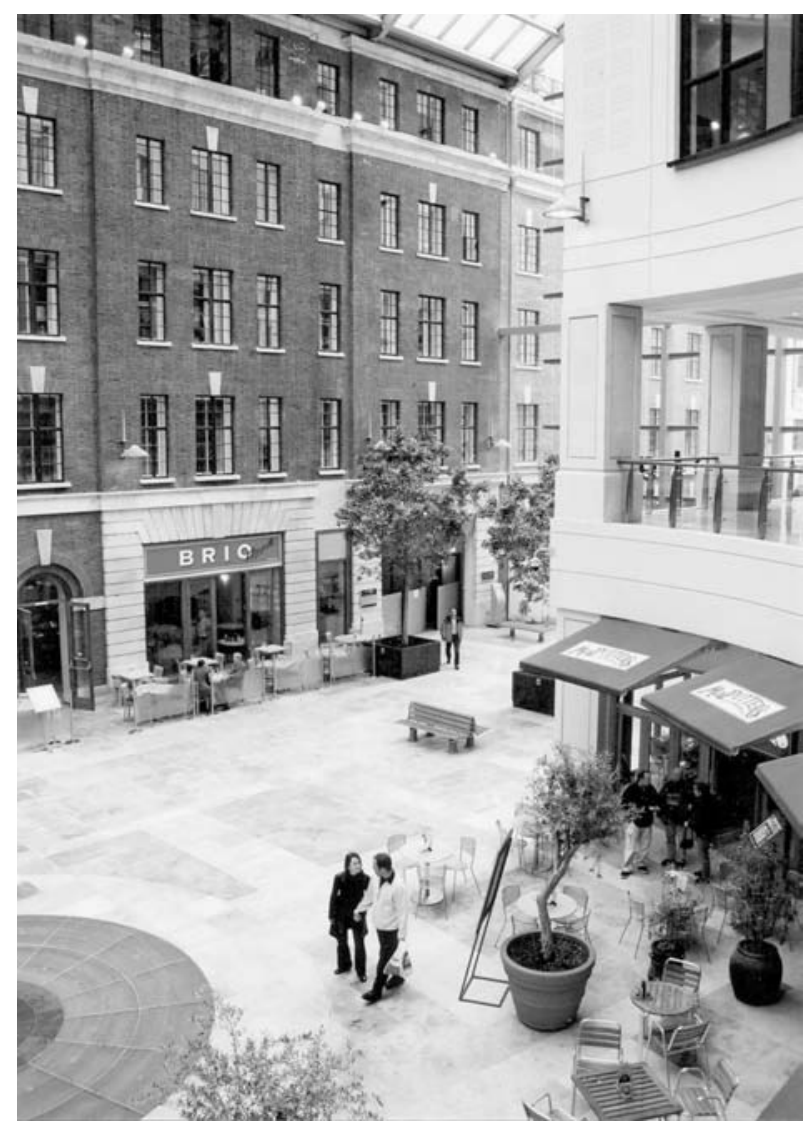

Figure 9: Link between courtyards facing Radisson Hotel

The client has adopted a very positive management style which has ensured good relations with the community with whom they have worked to support a comprehensive promotion programme. Partnerships have been built up with every tenant from day one,

Proactive management with an initial welcome pack, tenants' newsletters, a full PR service to help drive their business forward, one-to-one sessions with the management team and regular tenants' meetings. The Light website includes an individual page for each tenant and a loyalty scheme has been introduced in the form of the Elite Club, which provides customers every month with a special range of offers and discounts. Three touch-screen information points give visitors the opportunity to access their benefits and find out more about the retailers.

The service does not stop with the shopping. The car park is designed to be friendly and a partnership with the Automobile Association means that visitors can take advantage of a free vehicle recovery service and a tyre-changing facility. Late-night customers can also make use of a security escort to their cars (see Figure 10).

Thus the centre management have continued to build on the theme of creating a unique experience for the visitor - a selection of events including an innovative photographic exhibition, an 


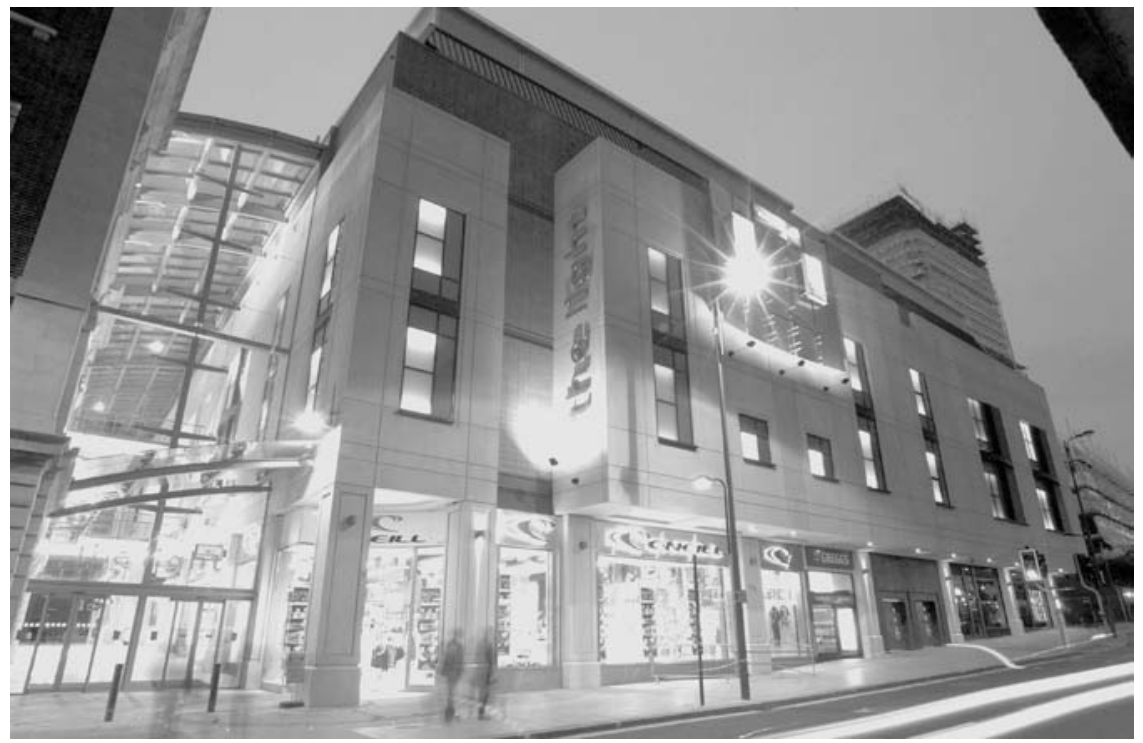

Figure 10: Night time entrance

interactive Wizard of $\mathrm{Oz}$ promotion, a style show, a film premier and after-show party and many other events are positioning The Light as the 'cool' place for leisure and shopping.

\section{CONCLUSION}

The Light is the very opposite of the traditional shopping centre or urban entertainment centre in that, unlike the usual inward-looking block with limited entrances and outlook, this building not only invites the city into its heart but also actively faces outwards to interact with its surroundings.

It has used the familiar and respected elements of the city to create the environment and the experience, which is reflected in awards from specialist bodies such as the British Council of Shopping Centres and the Leisure Property Forum, and community awards such as the Leeds People's Award are evidence of the affection with which it is already held by the community.

According to Pine and Gilmore's objectives, ${ }^{19}$ by making use of the historic fabric the development has customised the experience for the community. It has created a unique experience which, by being integrated with the town, is now part of that community's heritage.

There was a clear initial concept which reflected the aspirations of an experience economy to achieve integration with the community and viability for the historic buildings, allowing the many parties concerned to share a vision and see the project through, despite some very difficult and complex negotiations.

While it is clear that the early submission of a planning application was not ideal, in that many areas of design were still to be developed, this did allow detailed negotiation to take place, which in the event appears to have benefited the project. With hindsight it may be that some of the comments about the scale of 
the new building would now be withdrawn: it was necessary to create the buzz of activity and interaction which Mark Girouard describes as belonging to all great cities where the "throb and sensation of life ... lifts their hearts and stirs the blood', ${ }^{20}$ and possibly that was more difficult to understand for those like the 20th Century Society who focus only on a discrete element of the project. With hindsight a more comprehensive conservation analysis and statement could have assisted the design team and those invited to comment on the proposals, thereby saving time in the planning process.

Concerns about the arcade and the precise line of the glazing have proved unfounded, and the Leeds Civic Trust has described it as 'A splendid arcade which is Milanese in scale ... a majestic new public space for the city which also brought these splendid 1930s buildings sparkling back to life. ${ }^{21}$

A lesson for future mixed-use development of this type is the need for a commitment to the overall concept of integration from the outset. Such an attitude not only informs the design and disposition of the elements but eases negotiation, inspires the many and diverse stakeholders, and ultimately embodies the essence of a whole experience.

One is likely to see more developers who have to contend with the complications and constraints inherent in mixed-use developments and at the same time have the opportunity to derive benefit from the historic environment. The Light will remain a benchmark for their success for a considerable time to come.

\section{APPENDIX}

\section{The awards}

Yorkshire Property Award 2002 - Best Commercial Development RICS Pro-Yorkshire Award 2002 - Best Commercial Development Leisure Property Forum Award 2002 - Best Commercial Mixeduse Development

British Council of Shopping Centres - Special Award 2002

City of Leeds Awards 2002 - Best Altered Building

- People's Award

- Award for New Building

\section{The team}

Client - Halifax in conjunction with Clerical and Medical Insurance Group

Development Managers — St James Securities

Architects - DLG Architects

Structural Engineer - White Young Green

Services Engineer - John Ryan Partnership

Quantity Surveyor - Cyril Sweett

Fire Consultant - Arup Fire

Highways Consultant — Arup Highways 
Case study: The interaction between commercial objectives and conservation in a city-centre mixed-use development

\section{Acoustic Consultant - Sound Research Laboratories Planning Supervisor — Leslie Clark Project Management Contractor - Bovis Lend Lease, North Division}

\section{References}

1. Woolner, N. (2002) address at the BCSC Dinner, quoted in BCSC press release, 5 December.

2. Walker, A. (2001) 'Leisure heritage and the city: A potent combination', Journal of Leisure Property, Vol. 1 No. 3, pp. 209-219.

3. Girouard, M. (1985) The Uses of Leisure: Cities and People, Yale University Press, New Haven, CT, pp. 181-183.

4. Telling, A. E. (1967) Planning Law and Procedure, Butterworths, Oxford, pp. 1-9.

5. Hall, P. (1974) Planning for Cities and City Regions, Urban and Regional Planning, Pelican.

6. Amery, C. and Cruickshank, D. (1975) The Rape of Britain, Paul Elek.

7. Cullen, G. (1961) Townscape, Architectural Press, Oxford.

8. Crosby, T. (1973) How to Play the Environment Game, Penguin, London.

9. DLG Architects (1990) Retail Report 1990. A survey of design trends.

10. Property Week 'Experiential retailing', 13 December (2002), p. 39.

11. Pine, B. J. and Gilmore, J. H. (1999) The Experience Economy, Harvard Business School Press, Cambridge, Mass.

12. English Heritage (2002) Changing London, available at www.english-heritage.org.uk.

13. Tiesdell, S., Oc, T. and Heath, T. (1996) Revitalising Historic Urban Quarters, Architectural Press, Oxford

14. Frith, F. (1998) Around Leeds, Frith Book Company, p. 19.

15. Yorkshire Post (1935) Guide to the City of Leeds, p. 60.

16. Frith, ref. 14 above.

17. Department of Planning letter, 8 October 1997. While seeing many good points they considered that it 'represents an overdevelopment of the site which has led to a number of problems ...' Twentieth Century Society letter, 8 October 1997, welcomes the reuse of Permanent House and the approach to the interiors but feels that the new building is 'rather large and overbearing' while Leeds Civic Trust on 16 October 1997 wrote that 'As you will see we strongly support the overall concept. The treatment of the elevations of the new buildings and the inter-relationship with the cathedral are our main concerns.'

18. Data available at www.experian.com.

19. Pine and Gilmore, ref. 11 above.

20. Girouard, ref. 3 above, Introduction.

21. DLG Architects (2003) Project Review Sheet, January. Available at www.dlg-architects.com. 